\title{
The syndrome of 'continuous muscle-fibre activity' cured: further studies
}

\author{
HYAM ISAACS AND J. J. A. HEFFRON \\ From the Clinical Neuromuscular Research Unit, Department of Physiology, \\ and the Department of Physiological Chemistry, Witwatersrand University Medical School, \\ Johannesburg, South Africa
}

SYNOPSIS Two cases suffering from the syndrome of 'continuous muscle-fibre activity' have been followed-up for 14 years. These patients have gradually gone into remission and no longer require therapy. The results of recent histology, histochemistry, and electronmicroscopy, as well as sural nerve biopsy studies, are presented. The sarcoplasmic reticulum calcium binding activity and ATPase activity are normal.

In 1961 two cases of 'continuous muscle-fibre activity' were described (Isaacs, 1961). The typical features of this syndrome served to separate it from other known forms of neuromuscular disease. Since this time, a number of other typical cases have been described by Levy et al. (1965), Mertens and Zschocke (1965), Isaacs (1967), Buscaino et al. (1970), Desai et al. (1970), Wallis et al. (1970), and Welch et al. (1972). In 1960 after prolonged investigation diphenylhydantoinate was found to offer dramatic symptomatic relief from the continuous muscle-fibre activity. It was furthermore sug- gested that the muscle-fibre activity occurred in response to an abnormal release of acetylcholine by the motor nerve terminals.

The original two cases have now been followed-up for 14 years and over the past few years it was noticed that the manifestations of the disease were becoming less troublesome. Smaller doses of diphenylhydantoinate were needed until the present time when treatment is no longer necessary. The clinical improvement relates well with the muscle histology and histochemistry and these features are presented. The sural nerves have been biopsied, as it was sug-
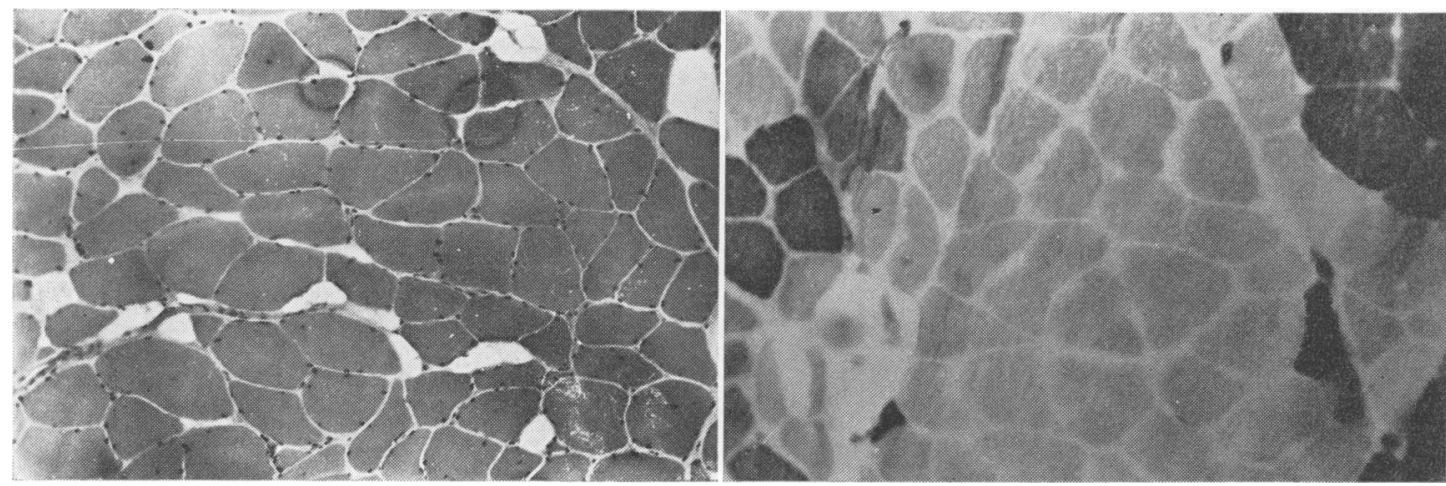

FIG. 1 (left). Showing increased variability of the size of muscle fibres. There is an increase in the number of central nuclei and several of the nuclei are larger than normal. $\times 35$. FIG. 2 (right). Myofibrillar ATPase stain showing an area of excessive grouping of the type I fibres. $\times 35$. 
gested by Welch et al. (1972) that sensory nerves may also be involved. In addition, the relaxing capacity of the isolated sarcoplasmic reticulum has been studied as well as actomyosin adenosinetriphosphate.

\section{METHODS}

Muscle tissue was removed at various times from three patients suffering from this disease. The muscles sampled included the pectoralis, vastus lateralis, peroneus longus, anterior tibial, and the deltoids. The histochemical and histological profiles included NAD diaphorase, myofibrillar ATPase, mitochondrial ATPase, phosphorylase, PAS stain for glycogen, modified trichrome stains, and routine haematoxylin and eosin (H and $\mathrm{E}$ ) stains.

The sural nerve segments were removed under local anaesthesia, maintained at resting length, and fixed in both formalin and osmic acid. Single fibre preparations were obtained with the use of the dissecting microscope after preparation in glycerine. Transverse and cross sections of nerve were cut after wax embedding and stained with $\mathrm{H}$ and $\mathrm{E}$. Muscle was also biopsied at the same time for electronmicroscopic study. This muscle was held in clamps to maintain the resting length and fixed in gluteraldehyde, processed, and then embedded in Epon. Thin sections were cut and examined with a Siemens Einskop electronmicroscope.

Sarcoplasmic reticulum was isolated from biopsy specimens of the $m$. vastus lateralis of one patient and muscle from three normal individuals was used as controls. The isolation procedure was essentially according to the method of Duggan (1971). Muscle was homogenized in 9 volumes of $0.3 \mathrm{M}$ sucrose $20 \mathrm{mM}$ imidazole- $\mathrm{HCl}, \mathrm{pH} 6 \cdot 85$, with an all-glass hand homogenizer at $2^{\circ} \mathrm{C}$. The homogenate was 0 centrifuged at $2,000 \mathrm{~g}$ for 10 minutes to sediment the $D$ myofibrillar fraction, which was then kept for extraction of actomyosin. The supernatant fluid was centrifuged twice at $15,000 \mathrm{~g}$ to remove the mitochondria. Sarcoplasmic reticulum was sedimented by

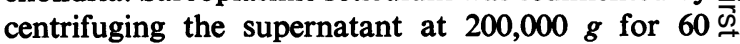
minutes, and resuspended in $1.0 \mathrm{ml}$ homogenizing? medium per gram of original tissue. The above procedures were carried out at $2^{\circ} \mathrm{C}$. ATPase and $\mathrm{Ca}^{2+}$ uptake studies were made immediately after prepara- $\stackrel{\Phi}{\Omega}$ tion of the sarcoplasmic reticulum using the millipore $\$$ filtration procedure of Martonosi and Feretos (1964), $\vec{\circ}$ and with the same substrate and protein concentrations described by Samaha and Gergaly (1965). The $\vec{\omega}$ $\mathrm{pH}$ of the assay medium was 6.85 and activities were $\stackrel{9}{2}$ measured at $37^{\circ} \mathrm{C}$. The assay medium contained $0.1 \mathrm{mM}{ }^{45} \mathrm{CaCl}_{2}(0.5 \mu \mathrm{Ci} / \mathrm{ml})$. (The rate of $\mathrm{Ca}_{0}^{2+}$ binding was measured after one minute's reactio and calcium uptake (total) after 10 minutes' reaction.in the assay medium.) Calcium uptake was computed by the method of Sylvester and Baskin (1973. E ATPase activity was measured as inorganic phospho liberated by the method of Taussky and Shorr (195.

Actomyosin ATPase was extracted from the my fibrillar fraction, mentioned above, in 5 volumes ffo $0.6 \mathrm{M} \mathrm{KCl}-25 \mathrm{mM}$ tris- $\mathrm{HCl}, \mathrm{pH} 7.3$ for 24 hours att $2^{\circ} \mathrm{C}$, after which it was purified by two cycles centrifugation at $20,000 \mathrm{~g}$ for 30 minutes a $\mathrm{ad} d \mathrm{\Phi}$ precipitation by dilution. Actomyosin ATPase $\vec{c}$ activity was measured at $30^{\circ} \mathrm{C}$ essentially according $\AA$

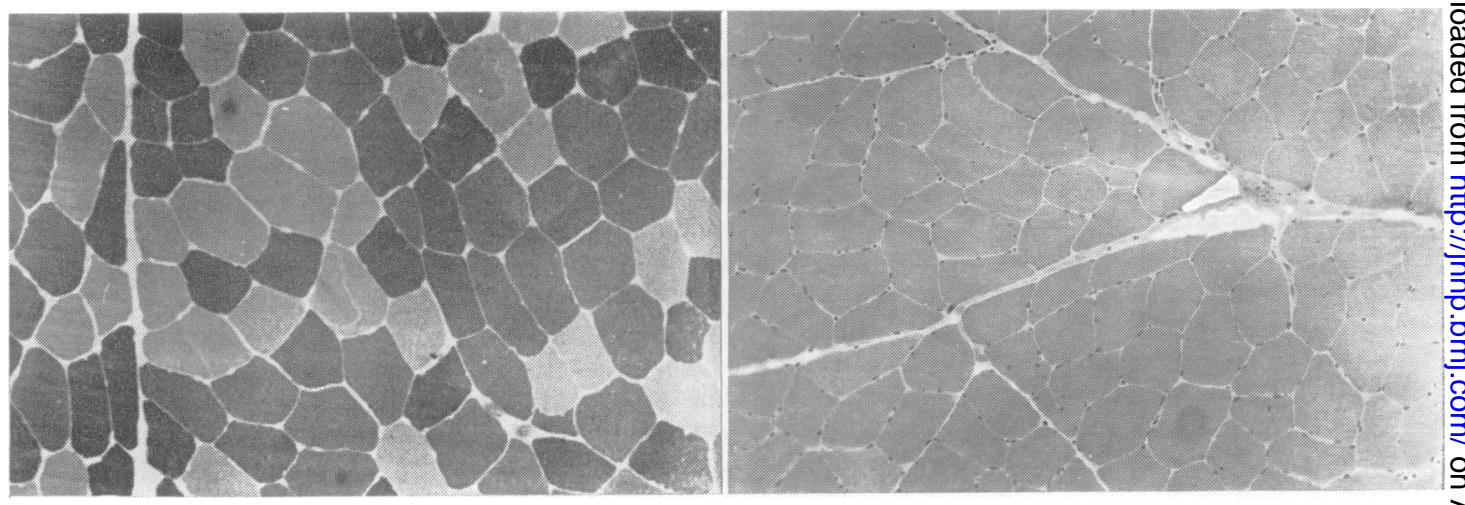

FIG. 3 (left). Myofibrillar ATPase stain showing a reasonably normal distribution of muscle fibre types. $\times 35 . \frac{2}{=}$ FIG. 4 (right). There is less variability in fibre size and central nuclei are less evident. Haematoxylin and eosin preparation. $\times 35$. 


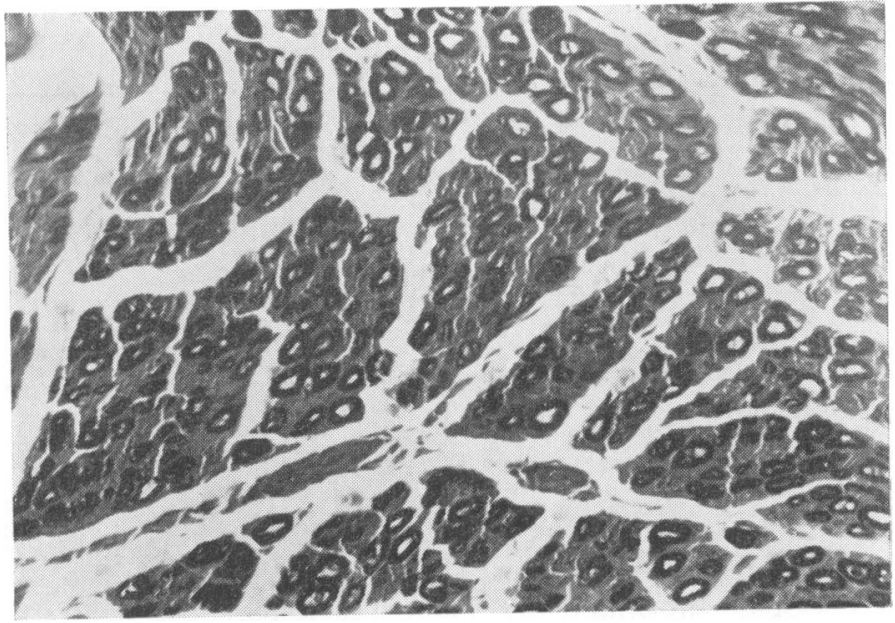

FIG. 5. Cross-section of the sural nerve showing a normal distribution of axons. Osmium tetroxide and haematoxylin and eosin preparation. $\times 160$.

FIG. 6. Electronmicrograph showing normal myofibrils with a centrally situated nucleus. $\times 4,000$.

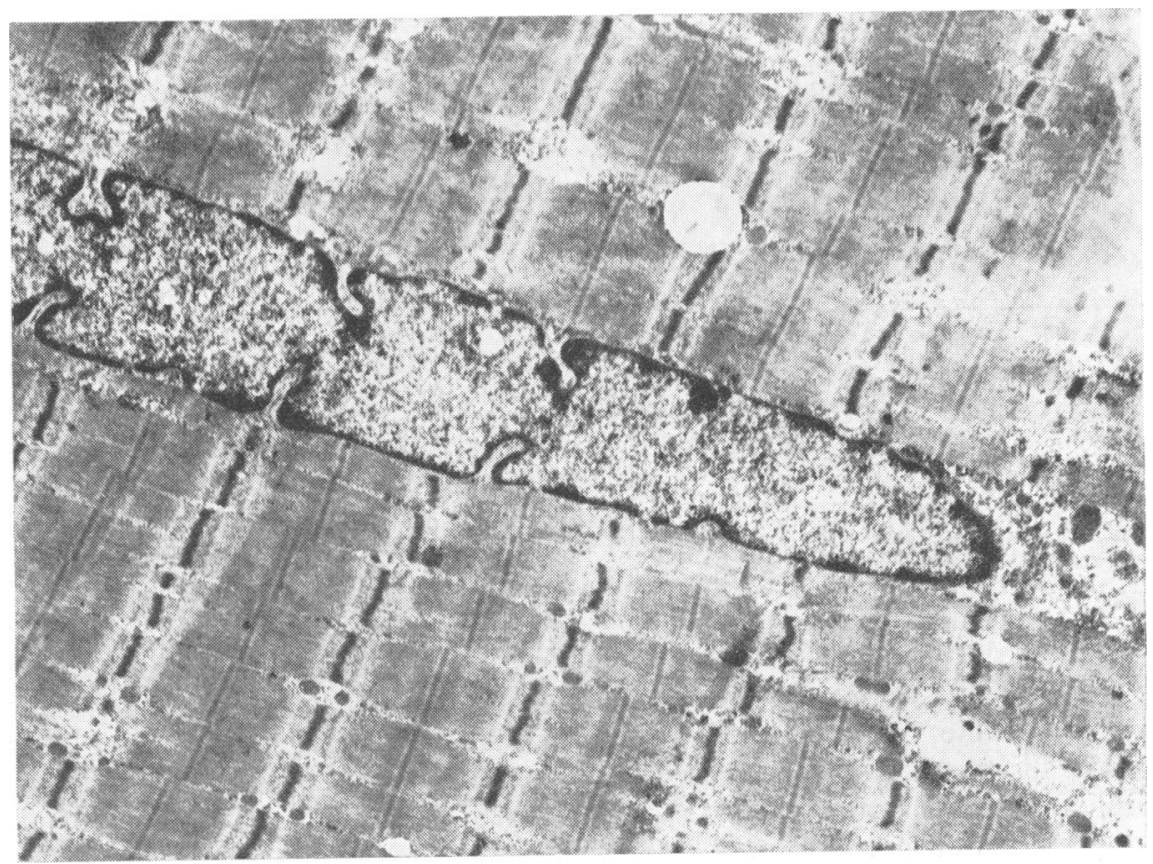

to Heffron and Duggan (1971) in the following assay media: abpH 7·3: $\mathrm{Mg}^{2+}$-ATPase: $5 \mathrm{mM}$ ATP-tris, $5 \mathrm{mM} \mathrm{MgCl}_{2}, \mathrm{u}=0.05: \mathrm{Ca}^{2+}$ ATPase: $5 \mathrm{mM}$ ATPtris, $5 \mathrm{mM} \mathrm{CaCl}_{2}, \mathrm{u}=0.5$; EDTA-ATPase: $5 \mathrm{mM}$ ATP-tris, $u=0.5$. Protein was estimated by the method of Lowry et al. (1951) using bovine serum albumin as standard.

\section{RESULTS}

The muscle histology and histochemistry over the past few years has shown that the abnormal variation in fibre size (Fig. 1) as well as the increased grouping of individual fibre types (Fig.2) has become less obvious (Fig. 3). The numerous 
TABLE 1

CALCIUM UPTAKE AND ATPASE ACTIVITY IN THREE NORMAL SUBJECTS AND PATIENT

\begin{tabular}{|c|c|c|c|c|c|c|}
\hline & \multicolumn{4}{|c|}{ Calcium uptake } & \multicolumn{2}{|c|}{ ATPase activity } \\
\hline & No oxalate & $5 \mathrm{mM}$ oxalate & No oxalate & 5 mM oxalate & No oxalate & Oxalate \\
\hline & \multicolumn{2}{|c|}{ Initial rate } & \multicolumn{2}{|c|}{ ( $\mu \mathrm{mol} / \mathrm{mg}$ protein in $10 \mathrm{~min})$} & \multicolumn{2}{|c|}{ ( $\mu \mathrm{mol} \mathrm{Pi} / \mathrm{mg}$ protein/min) } \\
\hline & \multicolumn{2}{|c|}{ ( $\mu \mathrm{mol} / \mathrm{mg}$ protein/min) } & & & & \\
\hline $\begin{array}{l}\text { Normal (3) } \\
\text { Patient }\end{array}$ & $\begin{array}{c}0.233 \pm 0.011 \\
0.218\end{array}$ & $\begin{array}{c}0.790 \pm 0.049 \\
0.696\end{array}$ & $\begin{array}{c}0.205 \pm 0.018 \\
0.138\end{array}$ & $\begin{array}{c}1 \cdot 958 \pm 0 \cdot 103 \\
1 \cdot 510\end{array}$ & $\begin{array}{c}0.200 \pm 0.012 \\
0.118\end{array}$ & $\begin{array}{c}0.676 \pm 0.021 \\
0.411\end{array}$ \\
\hline
\end{tabular}

Data are expressed as mean $\pm S E M$. All activities measured at $37^{\circ} \mathrm{C}$.

nuclei of degenerating and regenerating fibres are now few (Fig. 4). The sural nerves were found on both single fibre and cross-sectional studies to be normal (Fig. 5). The recent electronmicroscopic study of muscle removed from the vastus lateralis was within normal limits (Fig. 6).

The initial rate, total uptake of calcium, and ATPase activities of sarcoplasmic reticulum from

TABLE 2

ACTOMYOSIN ATPaSe ACTIVITIES OF NORMAL AND PREVIOUSLY DISEASED MUSCLE

\begin{tabular}{lccc}
\hline & ATPase activity & $C^{2+}$-ATPase & EDTA-ATPase \\
\cline { 3 - 4 } & & \multicolumn{2}{c}{ (umol Pi/mg protein/min) } \\
\hline Normal (3) & $0.239 \pm 0.017$ & $0.208 \pm 0.021$ & $0.647 \pm 0.045$ \\
Patient & 0.241 & 0.149 & 0.715 \\
\hline
\end{tabular}

Data are expressed as mean $\pm \mathrm{SEM}$. Enzyme activities measured at $30^{\circ} \mathrm{C}$.

the patient and three normal individuals are shown in Table 1. The initial rate of calcium binding by the sarcoplasmic reticulum in the presence and absence of $5 \mathrm{mM}$ oxalate, measured after one minute's reaction, is essentially the same in the controls and the patient, the normal ranges being $0.711-0.882$ and $0.245 \mu \mathrm{mol} \mathrm{Ca} / \mathrm{mg}$ protein $/ \mathrm{min}$, respectively. However, the total uptake of calcium in the presence and absence of oxalate was decreased by 17 and $25 \%$, respectively, when referred to the lower limit of the normal ranges. The $\mathrm{Mg}^{2+}$-activated ATPase activity of the sarcoplasmic reticulum of the patient, measured in the presence and absence of oxalate, was reduced by 37 and $34 \%$, respectively, compared with the lower limit of the $\vec{\circ}$ normal range. There was no real difference in the $\overrightarrow{\vec{\omega}}$ yield of sarcoplasmic reticulum from the patient and the controls, the values being 1.90 and $2.05 \pm 0.06 \mathrm{mg}$ of sarcoplasmic protein per gram of fresh tissue, respectively.

The $\mathrm{Mg}^{2+}$ - and EDTA-activated ATPase. activities of actomyosin were the same in the $\vec{N}$ patient and the control, while a small decrease was observed in the case of the $\mathrm{Ca}^{2+}$-activated 응 enzyme (Table 2).

\section{DISCUSSION}

The site of the abnormal discharge was localized to the motor nerve terminals (Isaacs, 1961, 196 $\overline{7}, \overrightarrow{0}$ 1967). It is, nevertheless, possible that some of the abnormal activity originates in more proximal sites of the motor nerves (Welch et al., 1972). The reduced sensory axonal population in the sural nerve in the patient of Welch et al. (1972) led them to believe that sensory involvement was also present in this syndrome. This finding, how- $\overrightarrow{\vec{P}}$ ever, was contrary to the clinical and electro- $\frac{}{3}$ physiological findings and as Arnold and Harriman (1970) have pointed out the suralo nerve findings are often misleading. Further to investigate this finding, sural nerve biopsies were taken from both the original patients ando found to be entirely normal (Fig. 5).

Over the passage of 14 years spontaneous gradual cure has occurred and this has been accompanied by improvement in the muscle? histology and histochemistry. Fibre type group $-\frac{7}{0}$ ing, in particular, is now far less evident. We realize that it is impossible to have accurate $N^{N}$ controls with muscle biopsy tissue, as the samen 
area cannot be re-examined, but the changes over the past 14 years suggest that the earlier peripheral involvement of the motor nerves having subsided has allowed the nerves to resume their normal stimulatory and trophic activity and reclaim their motor unit territory. The possibility of reclaiming motor unit territory has no experimental backing but it has been obvious from earlier motor end-plate and nerve terminal studies that double innervation of a single muscle fibre was common in this condition and so perhaps it is a question of re-establishing a physiological preponderance.

As far as the present biochemical studies are concerned, it is clear from the data presented that the initial rate of calcium binding is normal, indicating that the rate of relaxation is also normal. The small reduction in total calcium uptake observed may not be significant in view of the small number of controls tested. Although the $\mathrm{Mg}^{2+}$-activated ATPase activity of the sarcoplasmic reticulum of the patient was reduced, the ratio of initial rate of calcium binding to ATPase activity is slightly higher (Table 1). Thus the efficiency of calcium binding is not altered in the patient, suggesting that the relaxing mechanism is intact. Similarly, the content of sarcoplasmic reticulum in the muscle of the patient, measured as total protein in the isolated reticulum is normal. The contractile apparatus is intact as shown by the normal actomyosin ATPase activity of the patient. Thus the present clinical, histological, and histochemical findings are in general accord with the biochemical data, indicating that the patients' muscles have recovered almost completely. The eventual recovery of these patients gives no clue to the initial causative mechanism but tends to rule out an inherited abnormality.

We wish to thank the National Council for the Care of Cripples South Africa, the Medical Research Council, the Witwatersrand University Senate Research Fund, and the Atomic Energy Board for funds made available for various aspects of neuromuscular research.

\section{REFERENCES}

Arnold, N., and Harriman, D. G. F. (1970). The incidence of abnormality in control human peripheral nerves studied by single axon dissection. Journal of Neurology, Neurosurgery, and Psychiatry, 33, 55-61.

Buscaino, G. A., Caruso, G., Giacomo, P. de, Labianca, O., and Ferrannini, E. (1970). Patologia Neuromusculare Insolita. Nota 1: Reperti elettromiografici ed istoenzimatici muscolari in un soggetto con 'sindrome de attività muscolare continua' ('neuromiotonia'). Acta Neurologica, 25, 206-224.

Desai, A. D., Pandya, S., and Raju, T. N. K. (1970). Continuous muscle fibre activity (Isaacs). Neurology (Bombay), 18, 101-106.

Duggan, P. F. (1971). Stimulation of calcium uptake of muscle microsomes by phenothiazines and barbiturates. European Journal of Pharmacology, 13, 381-386.

Heffron, J. J. A., and Duggan, P. F. (1971). Adenosinetriphosphatase activity and superprecipitation of actomyosin from the frog, Rana temporaria. International Journal of Biochemistry, 2, 324-336.

Isaacs, H. (1961). A syndrome of continuous muscle-fibre activity. Journal of Neurology, Neurosurgery, and Psychiatry, 24, 319-325.

Isaacs, H. (1964). Quantal squander. South African Journal of Laboratory and Clinical Medicine, 10, 93-95.

Isaacs, H. (1967). Continuous muscle fibre activity in an Indian male with additional evidence of terminal motor fibre abnormality. Journal of Neurology, Neurosurgery, and Psychiatry, 30, 126-133.

Levy, J. A., Wittig, E. O., and Ferraz, E. C. F. (1965). Esclerodermia associada a atividade elétrica muscular contínua. Arquivos de Neuro-psyquiatria, 23, 283-287.

Lowry, O. H., Rosebrough, N. J., Farr, A. L., and Randall, R. J. (1951). Protein measurement with the Folin phenol reagent. Journal of Biological Chemistry, 193, 265-275.

Martonosi, A., and Feretos, R. (1964). The uptake of $\mathrm{Ca}^{++}$ by sarcoplasmic reticulum fragments. Journal of Biological Chemistry, 239, 648-658.

Mertens, H.-G., and Zschocke, S. (1965). Neuromyotonia. Klinische Wochenschrift, 43, 917-925.

Samaha, F. J., and Gergely, J. (1965). $\mathrm{Ca}^{++}$uptake and ATPase of human sarcoplasmic reticulum. Journal of Clinical Investigation, 44, 1425-1431.

Sylvester, R., and Baskin, R. J. (1973). Kinetics of calcium uptake in normal and dystrophic sarcoplasmic reticulum. Biochemical Medicine, 8, 213-227.

Taussky, H. H., and Shorr, E. (1953). A microcolorimetric method for the determination of inorganic phosphorus. Journal of Biological Chemistry, 202, 674-685.

Wallis, W. E., Van Poznak, A., and Plum, F. (1970). Generalized muscular stiffness, fasciculations, and myokymia of peripheral nerve origin. Archives of Neurology (Chic.), 22, 430-439.

Welch, L. K., Appenzeller, O., and Bicknell, J. M. (1972). Peripheral neuropathy with myokymia, sustained muscular contraction, and continuous motor unit activity. Neurology (Minneap.), 22, 161-169. 